\title{
Modifying Alternate Bearing of Spur-Type 'Delicious' Apple with Ethephon
}

\author{
Martin J. Bukovac ${ }^{1}$ and Paolo Sabbatini \\ Department of Horticulture, Michigan State University, East Lansing, \\ MI 48824-1325
}

\section{Philip G. Schwallier \\ Clarksville Horticultural Experiment Station, Michigan State University, 9302 Portland Rd., Clarksville, MI 48815}

Additional index words. biennial, 2-chloroethylphosphonic acid, flower initiation, Malus domestica, Redchief, return bloom

\begin{abstract}
The effect of ethephon on flowering and cropping of strongly alternate bearing spur-type 'Delicious' apple (Malus domestica Borkh.) was evaluated in a 6-year study. Ethephon (200 $\left.\mathrm{mg} \cdot \mathrm{L}^{-1}\right)$, applied at 3, 3+6, and $3+6+9$ weeks after full bloom in "on years," increased flowering in "off years" by $33 \%$ and reduced flowering in "on years" by $17 \%$ compared with the control. The mean yield per tree for ethephon-treated trees over three "on years" and three "off years" was almost identical to that of the controls (82 vs. $80 \mathrm{~kg} /$ tree). However, the distribution of yield between "on" and "off" years was changed, 24\% greater in "off years" and 10\% less in "on years." Ethephon reduced both the variation in yield, particularly in "off years," and the magnitude of alternation. Ethephon had a direct effect on flower initiation because 1) it did not reduce shoot growth or yield in the "on years" (years of ethephon application) and 2) ethephon-treated trees initiated more flowers per kilogram of fruit produced than did the controls. The additional flowers initiated were functional because the amount of fruit produced per unit bloom density did not differ between control and ethephon-treated trees. Harvest maturity indices, namely internal ethylene concentration, firmness, starch index, soluble solids, and color, were not significantly affected, although internal ethylene concentration and starch index tended to be higher in fruit from treated trees.
\end{abstract}

Alternate bearing is a common physiological problem characterized by overcropping followed by undercropping, which often limits the commercial usefulness of some apple cultivars. Researchers have studied the causes of and methods for reducing alternate bearing for decades, and the findings have been extensively reviewed (Davis, 1957; Hoblyn et al., 1936; Jonkers, 1979; Monselise and Goldschmidt, 1982; Singh, 1948; Williams, 1979). It is generally accepted that environmental events like severe frost or drought may induce alternate cropping in regularly cropping trees by severely reducing crop load (Monselise and Goldschmidt, 1982). Often the intensity of alter-

Received for publication 22 May 2006. Accepted for publication 22 July 2006.

We appreciate the assistance of Jerome Hull, Gail Byler, John Gilmore, Royal Fader, and Denise Ruwersma in collecting bloom and yield data; Randy Beaudry in the fruit maturity study; and Moritz Knoche and Michael Schroeder for extensive discussions and a critical reading of an earlier version of the manuscript.

Partial funding for these studies was provided by the Michigan Apple Research Committee, Lansing, Mich., and the Amos Farms, Williamsburg, Mich. ${ }^{1}$ To whom reprint requests should be addressed; e-mail bukovacm@msu.edu. nation may be reduced by minimizing overcropping. Hand thinning in high crop years can be effective if performed sufficiently early during fruit development, but often this practice is not commercially feasible (Byers, 2002; Williams, 1979). Chemical blossom and early fruit thinning have been more effective not only because fruit removal can be achieved early, but fruit thinning with some chemicals, e.g., naphthylacetic acid (NAA), may result in greater return bloom than can be attributed to the reduction in crop load (Bukovac, 1968; Harley et al., 1958).

Several growth regulators, namely daminozide, paclobutrazol, 2,3,5-triiodobenzoic acid (TIBA), NAA, and ethephon, have been shown to promote flowering in young, vigorous apple trees (Batjer et al., 1964; Bukovac, 1968; Byers and Barden, 1976; Luckwill, 1970; Voltz and Knight, 1986). Daminozide and ethephon, at high concentrations (1000 $\mathrm{mg} \cdot \mathrm{L}^{-1}$ ), reduce shoot growth, whereas TIBA and NAA $\left(25-50 \mathrm{mg} \cdot \mathrm{L}^{-1}\right)$ promote flowering with no significant effect on shoot elongation. Also, if ethephon induces early fruit abscission, return bloom may be increased in cropping trees (Byers, 1993; Greene et al., 1977; Marini, 1996). In most studies in which plant growth substances were used for thinning, the effect on return bloom was a secondary objective and limited to observation of bloom the next spring, and the effects on yield were seldom followed in subsequent years.

The objective of our study was to evaluate the effect of ethephon, without adjusting crop load, on bloom and yield of mature 'Delicious' trees, in a strongly alternate bearing cycle, over several consecutive seasons (1998-2004).

\section{Materials and Methods}

Plant material and cultural practices. Strongly alternate bearing 17-year-old Redchief 'Delicious'/MM.111 trees, in an "on year," growing on a virgin site at the Clarksville Horticultural Expt. Station, were selected for this study. Trees $(3.0 \times 6.0 \mathrm{~m})$ were trained to a central leader and winter pruned annually to maintain comparable canopies. Water sprouts, if excessive, were removed in late summer. Irrigation was provided as needed and no blossom or fruit thinning was performed. Two beehives were provided per acre in the orchard during bloom. Recommended crop protection practices were followed. These trees were uniform in size, form, and vigor. Crop load of record trees $(\mathrm{n}=96)$ was uniform in the initial year (1998), being $121 \mathrm{~kg} /$ tree, SD 23, and CV 19\%.

Ethephon application. Treatments consisted of a nonsprayed control and ethephon (200 mg. $\mathrm{L}^{-1}$ a.i.) as high-volume sprays $\left(\approx 1950-2150 \mathrm{~L} \cdot \mathrm{ha}^{-1}\right)$ applied once, twice, or three times at 3, 3+6, and $3+6+9$ weeks after full bloom (WAFB), respectively. The desired spray volume was established by measuring the volume used to provide first evidence of spray drip from leaves on the lower quadrant next to the spray lane using a FMC 350 series speed sprayer. Ethephon was applied in each of the three "on years" $(1998,2000,2002)$ of this 6-year (19982004) study. No surfactant was added. Mean king fruit diameters over 3 years were $\approx 11$, 29 , and $46 \mathrm{~mm}$ at time of the $3,3+6$, and $3+$ $6+9$ WAFB treatments, respectively.

Bloom density rating, yield, fruit and flower number per tree, floral initiation index, and biennial bearing index. Bloom density for each tree was visually rated (BR) 1 (lowest) to 10 (highest) annually by five to seven horticulturists (five individuals being the same each year) based on an estimate of percentage of a heavy bloom ("snowball"). Yield (total weight) was determined on each tree annually $(\mathrm{n}=96$, see "Experimental Design"). Number of fruit per tree was determined (20 individual trees having the highest yield) on harvested fruit using a Compac-Computerized Grading System, Auckland, NZ. Fruit number on the highest yielding trees varied from 840 to 1219 with a mean of 1013 fruit/tree. Assuming fruit set of $10 \%$, the estimated number of flowers per tree would be 10,130 . To simplify calculations, we assigned a value of 10,000 flowers per tree, and allocated 1000 flowers to each of the 10 BR units.

A flower initiation index was calculated by dividing flower number per tree by yield 
(kilograms per tree), in the previous season, giving flower number per kilogram of fruit. Treatment effects on bloom quality were assessed by calculating the weight (in kilograms) of fruit produced per unit of bloom for each of the first 3 years (frost-free, 2 "off years," 1999, 2001, and 1 "on year," 2000).

Alternation of cropping was evaluated for the first 4 frost-free years (1998-2001) by procedures developed by Hoblyn et al. (1936). Two parameters were calculated, B and I. Parameter B describes the degree of alternation based on the direction of yield (+ increase, - decrease) in consecutive pairs of years. The number of changes in direction over some given numbers of pairs of years is expressed as a percentage value. Parameter I describes the intensity (fluctuation) of alternation. Here a numeric value is obtained by calculating the difference in yield between two consecutive years and dividing by their sum. I varies from 0 to 1 ( 0 denotes uniform cropping, 1 denotes strongly biennial). This estimation is best when calculated over several consecutive pairs of years. It may be averaged (often $\times 100$ and expressed as percent) and used for comparative purposes (Pearce and Doberšek-Urbanc, 1967).

Shoot growth and preharvest drop. Shoot extension was monitored visually during active growth, and a preliminary measurement $(\approx 10$ shoots/tree) was made in mid-August of the first year of the study. Shoot extension was variable, but there was no evidence of marked inhibition of growth. In subsequent years, trees were visually evaluated every 7 to $10 \mathrm{~d}$; because there was no apparent inhibition of shoot growth, further measurements were not made. Preharvest drop was visually monitored and, if not excessive and similar among treatments, the dropped fruit was collected and added to the yield of harvested fruit. In only one season (1999, an "off year"), preharvest fruit drop was excessive in all treatments and the abscised fruit were weighed, but differences were not significant, and they were added to the harvested fruit.

Effect on harvest maturity. Ethephon effects on fruit maturity were evaluated in the second "on year" (i.e., after two "on year" ethephon treatments) by measuring internal ethylene concentration (IEC), firmness, starch index, soluble solids, and color, both red coloration and background, on samples of 10 fruit collected randomly from each treatment in each replication $(n=40)$. Samples were collected weekly starting 2 weeks before the projected harvest date for long-term storage. Fruit from nontreated guard rows were used to establish the predicted harvest date. Procedures for prediction of harvest date and maturity indices were as described by Beaudry et al. (1993) and Watkins et al. (2005), respectively.

Experimental design and statistics. A randomized complete block design of four treatments replicated four times was used. To facilitate spray application and minimize spray drift contamination, each treatment was assigned to a block of six contiguous record trees with two buffer trees between each treatment within a row. Each replication was assigned to a single row separated by at least one buffer row. Analysis of bloom and yield data were performed using the means of the six trees comprising each treatment. Basic statistics, analysis of variance, and regression analysis were performed using SAS programs (SAS Institute, Cary, N.C.) or Sigma Plot (SPSS, Chicago).

Frost event. A significant postbloom frost occurred in the fifth year (2002, seven and eight $\mathrm{d}$ after full bloom) of our study, which did not affect collection of our bloom data, but we estimated that yield was reduced by $\approx 58 \%$. After serious consideration, we decided to complete this 6-year study as originally designed (i.e., continue to collect yield data in 2002 and 2003 and bloom data in 2003 and 2004). This would illustrate the impact of the frost not only on yield in 2002 , but also on the alternation profile of bloom and yield after a significant frost.

\section{Results}

Effect on bloom. Multiple applications of ethephon in the "on years" (1998, 2000, 2002) significantly increased bloom in the following "off years" (1999, 2001, 2003) and reduced bloom in two of the three "on years" (2002, 2004) compared with the control and, with two exceptions (2000, 2004), to a single ethephon application (Table 1). In all years, bloom did not differ significantly between the two and three application treatments and, with one exception (2003), year after the 2002 frost, the single application did not differ from the control (Table 1). The return bloom in the second "off year" (2001) after ethephon treatment in two consecutive "on years" $(1998,2000)$ is illustrated for a single replication in Figure 1.
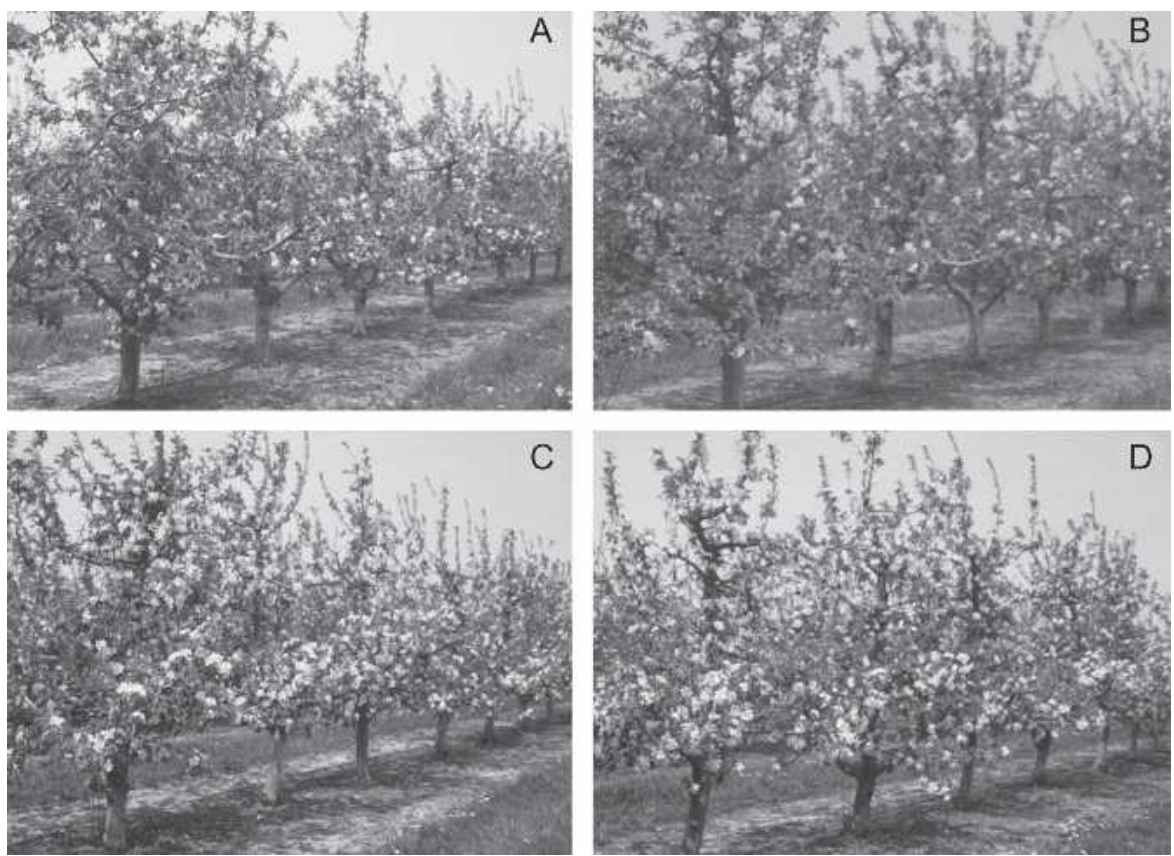

Fig. 1. Photographs of Redchief 'Delicious' trees (in a single replication, six trees per treatment) in the second "off year" after ethephon treatment $\left(200 \mathrm{mg} \cdot \mathrm{L}^{-1}\right)$ in the 2 consecutive previous "on years" (1998, 2000); (A) nontreated control; ethephon applied, (B) 3, (C) 3+6, and (D) $3+6+9$ weeks after full bloom. Mean bloom rating for A, B, C, and D was 4.1, 3.6, 6.9, and 7.1, respectively.

Repeated applications (two and three) of ethephon increased return bloom in this replication by $\approx 70 \%$; the single application was without effect.

Effect on yield. There were no significant differences in yield between the control and single ethephon treatment at 3 WAFB in any of the six years of this study (Table 2). Multiple ethephon applications increased yield significantly over both the control and a single application in the first two "off years" $(1999,2001)$, but not in the third "off year" (2003), the year after frost (Table 2). Ethephon had no effect on yield in the 1998 and 2000 "on years," but yield of the triple application in the third "on year" (2002), the year of the frost, was significantly lower.

Table 1. Effect of ethephon $\left(200 \mathrm{mg} \cdot \mathrm{L}^{-1}\right)$ applied as one, two, or three foliar sprays in 3 consecutive "on years" (1998, 2000, 2002) on flowering of Redchief "Delicious",

\begin{tabular}{lcccc}
\hline & \multicolumn{4}{c}{ Ethephon } \\
\cline { 2 - 5 } Yr (off/on) & NTC & 3 & $3+6$ & WAFB $^{\text {W }}$ \\
\hline & \multicolumn{4}{c}{ (Bloom density) } \\
1999 (off) & $1.7 \mathrm{a}$ & $1.9 \mathrm{a}$ & $2.4 \mathrm{~b}$ & $2.6 \mathrm{~b}$ \\
2000 (on) & $7.7 \mathrm{a}$ & $8.0 \mathrm{a}$ & $7.5 \mathrm{a}$ & $7.3 \mathrm{a}$ \\
2001 (off) & $4.0 \mathrm{a}$ & $4.3 \mathrm{a}$ & $5.2 \mathrm{~b}$ & $5.4 \mathrm{~b}$ \\
2002 (on) & $6.6 \mathrm{a}$ & $6.7 \mathrm{a}$ & $4.8 \mathrm{~b}$ & $4.8 \mathrm{~b}$ \\
2003 (off) & $6.2 \mathrm{a}$ & $7.2 \mathrm{~b}$ & $8.1 \mathrm{c}$ & $8.3 \mathrm{c}$ \\
2004 (on) & $6.6 \mathrm{a}$ & $6.3 \mathrm{a}$ & $5.0 \mathrm{~b}$ & $5.7 \mathrm{~b}$ \\
\hline
\end{tabular}

${ }^{\mathrm{z}} \mathrm{WAFB}$, weeks after full bloom.

${ }^{\mathrm{y}} \mathrm{Bloom}$ density rating from 1 to 10 (highest); see text for details.

Means within a year followed by the same letter are not significantly different at $P=0.05$ by Tukey's HSD test.

\section{(1)}


Table 2. Effect of ethephon (200 mg. $\left.\mathrm{L}^{-1}\right)$ applied as one, two, or three foliar sprays in 3 consecutive "on years" $(1998,2000,2002)$ on yield of Redchief 'Delicious'.

\begin{tabular}{lrrrr}
\hline & \multicolumn{4}{c}{ Ethephon $(\mathrm{kg} / \text { tree })^{\mathrm{z}}$} \\
\cline { 2 - 5 } Yr (off/on) & \multicolumn{1}{c}{ NTC } & \multicolumn{1}{c}{$3+6+9$} \\
\hline 1998 (on) & $125.3 \mathrm{a}$ & $111.3 \mathrm{a}$ & $123.5 \mathrm{a}$ & WAFB $^{\mathrm{y}}$ \\
1999 (off) & $30.2 \mathrm{a}$ & $33.8 \mathrm{a}$ & $50.2 \mathrm{~b}$ & $56.2 \mathrm{~b}$ \\
2000 (on) & $128.6 \mathrm{a}$ & $121.1 \mathrm{a}$ & $119.2 \mathrm{a}$ & $121.2 \mathrm{a}$ \\
2001 (off) & $53.8 \mathrm{a}$ & $51.6 \mathrm{a}$ & $69.0 \mathrm{~b}$ & $69.2 \mathrm{~b}$ \\
2002 (on) $^{\mathrm{x}}$ & $52.8 \mathrm{a}$ & $47.8 \mathrm{a}$ & $32.8 \mathrm{a}$ & $25.8 \mathrm{~b}$ \\
2003 (off) & $89.3 \mathrm{a}$ & $91.1 \mathrm{a}$ & $95.2 \mathrm{a}$ & $95.3 \mathrm{a}$ \\
\hline
\end{tabular}

${ }^{\mathrm{z}}$ Means within a year followed by the same letter are not significantly different at $P=0.05$ by Tukey's HSD test.

'WAFB, weeks after full bloom.

${ }^{x}$ Frost in 2002 interrupted the alternate bearing cycle and established 2002 as an "off-year" and 2003 as a potential "on-year."

Effect on alternation of bloom and yield. Alternations in bloom and yield were pronounced throughout this study (Fig. 2). The amplitude in bloom density varied from $60 \%$ to $70 \%$ less to $40 \%$ to $60 \%$ more than the general mean for the control $(5.5 \pm 2.3)$ in the "off years" and "on years," respectively (Fig. 2). The effect of a single ethephon treatment did not differ from that of the control, except in 1 year (2003), and the profile over six years was almost identical. Similarly, the bloom profiles for the multiple applications were identical (Fig. 2). Multiple applications in "on years" increased bloom significantly in the "off years" and consistently decreased yield, but to a lesser extent, in the "on years" (Fig. 2, inset). The bloom profile of the single ethephon treatment was similar to that of the control.

Alternation of yield over the six years was similar to that of bloom, except in 2002 when yield was reduced by frost (Fig. 2). Thus, the frost interrupted the profile pattern in 2002 and established 2003 as the "apparent" next "on year." Like with bloom, the yield profiles for the control and the single ethephon treatment were essentially identical as were the profiles for the multiple ethephon treatments (Fig. 2, inset). When yield data were expressed on a percent of control basis, marked increases in yield were obtained in the two frost-free "off years" but no significant effect in the intervening "on years" (Fig. 2, inset).

Parameters calculated to estimate tendency (B) and intensity (I) of alternation confirmed a high degree of cropping bienniality in our trees. The calculated B was 100 , the highest possible (0-100), and I ranged between $63 \%$ and $42 \%$ for the "on/off" paired years and $64 \%$ for the "off/on" paired years, respectively (Table 3 ). Ethephon applied at $3+6$ and $3+6+9$ WAFB decreased the intensity of alternation by $\approx 35 \%$. A single ethephon application at 3 WAFB was without effect, and the multiple applications did not differ from each other (Table 3 ).

Long-term effect on bloom density and yield. Because, with few exceptions, the single ethephon application did not differ

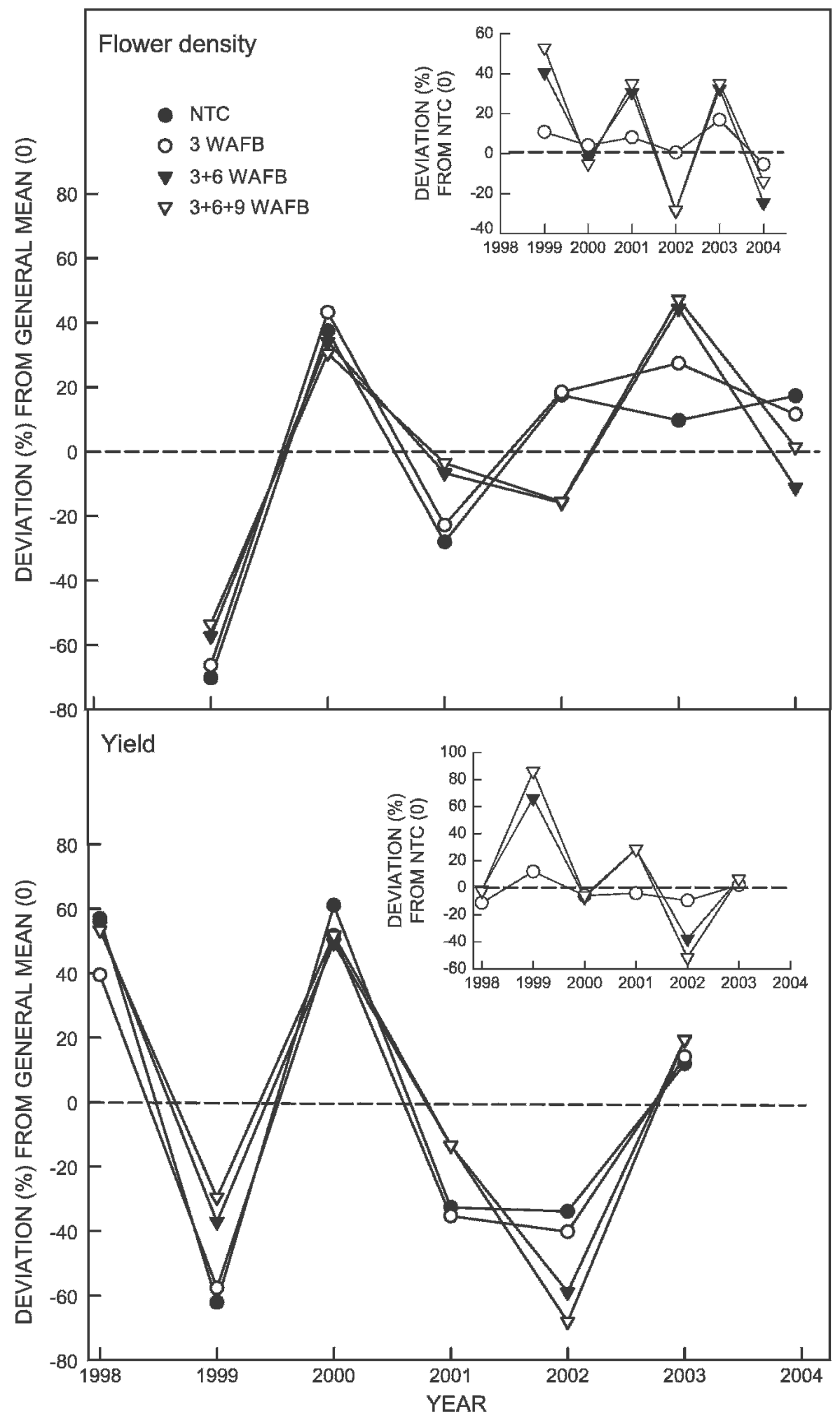

Fig. 2. Effects of ethephon $\left(200 \mathrm{mg} \cdot \mathrm{L}^{-1}\right)$ applied in three consecutive "on years" $(1998,2000,2002)$ on deviation (\%) of flower density and yield ( $\mathrm{kg} / \mathrm{tree})$ from the general mean for three "on years" and intervening "off years." Insets: Data as percentage of control for each year. NTC and WAFB denote nontreated control and weeks after full bloom, respectively.

from the control, and the multiple ethephon treatments did not differ from each other, we used data from the control and the double application $(3+6$ WAFB) to illustrate the long-term effects of ethephon on bloom density and yield. The mean bloom rating for the control over three "on years" and three "off years" was 7.0 and 4.0, respectively, and for the ethephon treatment, 5.8 and 5.3, respectively (Table 4). The general means for control and ethephon over the 6 years of the study (3 “on" +3 "off") were 
Table 3. Effect of ethephon $\left(200 \mathrm{mg} \cdot \mathrm{L}^{-1}\right)$ applied at 3, 3+6, and $3+6+9$ weeks after full bloom (WAFB) on intensity of alternation (I) of spur-type 'Delicious'.

\begin{tabular}{llccc}
\hline & \multicolumn{4}{c}{ Ethephon $^{\mathrm{y}}$} \\
\cline { 2 - 5 } Yr. $^{\mathrm{x}}$ & NTC & 3 & $3+6$ & $3+6+9 \mathrm{WAFB}^{\mathrm{z}}$ \\
\hline $1998 / 1999$ (on/off) & $63 \mathrm{a}$ & $54 \mathrm{ab}$ & $43 \mathrm{bc}$ & $39 \mathrm{c}$ \\
$1999 / 2000$ (off/on) & $64 \mathrm{a}$ & $57 \mathrm{a}$ & $41 \mathrm{~b}$ & $39 \mathrm{~b}$ \\
$2000 / 2001$ (on/off) & $42 \mathrm{a}$ & $41 \mathrm{a}$ & $27 \mathrm{~b}$ & $26 \mathrm{~b}$ \\
\hline
\end{tabular}

${ }^{\mathrm{z}}$ Data are calculated I values $\times 100$ with signs ignored. The calculated $\mathrm{B}$ parameter was 100 , the highest possible (range, 1-100).

${ }^{x}$ Yield from indicate years used to calculated I

${ }^{y}$ Means within a row followed by the same letter are not significantly different at $P=0.05$ by Tukey's HSD test.

Table 4. Mean effect of ethephon $\left(200 \mathrm{mg} \cdot \mathrm{L}^{-1}\right)$ applied at $3+6$ weeks after full bloom in three consecutive "on years" (1998, 2000, 2002) on flowering over six cropping seasons (three "on" and three "off") of Redchief 'Delicious' apple trees.

\begin{tabular}{lccr}
\hline & \multicolumn{2}{c}{ Mean bloom rating $(1-10)^{\mathrm{z}}$} \\
\cline { 2 - 4 } Parameter & "On years" "Off years" & Mean \\
\hline NTC & $7.0^{2}$ & 4.0 & 5.5 \\
Ethephon & 5.8 & 5.3 & 5.6 \\
Percentage of NTC & 83 & 133 & 102 \\
\hline $\mathrm{z}_{\mathrm{n}=72}$ & &
\end{tabular}

$z_{n}=72$.

Table 5. Mean effect of ethephon $\left(200 \mathrm{mg} \cdot \mathrm{L}^{-1}\right)$ applied at $3+6$ weeks after full bloom in three consecutive "on years" (1998, 2000, 2002) on yield over six seasons (three "on" and three "off") of Redchief 'Delicious' apple trees.

\begin{tabular}{lccr}
\hline & \multicolumn{3}{c}{ Yield (kg/tree) } \\
\cline { 2 - 4 } Parameter & "On years" "Off year" & Mean \\
\hline NTC & $102^{\mathrm{z}}$ & 58 & 80 \\
Ethephon & 92 & 72 & 82 \\
Percentage of NTC & 90 & 124 & 103 \\
\hline
\end{tabular}

${ }^{n} \mathrm{n}=72$.

almost identical, 5.5 versus 5.6. Ethephon depressed flowering by $17 \%$ in the "on years" and increased flowering by $33 \%$ in the "off years" (Table 4).

The effect of ethephon on yield over the course of the experiment was similar to that on bloom (Table 5). The mean yield for the control for the three "on years" was $102 \mathrm{~kg} /$ tree versus $58 \mathrm{~kg} /$ tree for the three "off years," whereas yields for the ethephon treatments were 92 and $72 \mathrm{~kg} /$ tree, respectively. The total yields over six years for control and ethephon treatments were the same ( $80 \mathrm{vs.} 82 \mathrm{~kg} /$ tree). Ethephon depressed yield by $10 \%$ in the "on years" and increased yield by $24 \%$ in the "off years" (Table 5 ).

Effect on flower initiation and flower quality. Ethephon applied in "on years" at $3+6$ and $3+6+9$ WAFB increased flower initiation, compared with the NTC, by $43 \%$ to $64 \%$ in trees carrying a high crop load of $\approx 123 \mathrm{~kg}$ per tree (Tables 2 and 6). Normalized for crop load, a similar increase of $44 \%$ to $50 \%$ was observed in the following "on year" (Table 6). In absolute terms, six to 16 more flowers were initiated per kilogram of crop load on ethephon-treated trees than on the NTC (Table 6).

Ethephon did not affect fruit setting potential of the flowers as indexed by yield of fruit produced per unit of bloom density, within each of the three years, two "off years" and one "on year" (Table 7). Thus, the additional flowers in the 1999 and 2001 "off years" attributed to ethephon (Table 1) were functional (Table 7). Also, these data confirm that ethephon treatments in the "on year" (2000) did not induce significant fruit abscission.

Effect on fruit maturity. The ethephon treatments did not significantly alter the IEC, firmness, starch index, soluble solids, and color (data not presented) within a given sampling date (Table 8). Data with basic statistics for control and ethephon applied at $3+6$ WAFB are presented in Table 8 for reference to other studies. There was a slight trend for an increase in the starch index and soluble solids with time of sampling, but no change in firmness. There was a more pronounced increase in IEC over the 14-d sampling period immediately before harvest and levels were consistently higher in the ethephon treatment (Table 8). The increase in the percentage of fruit with IEC greater than $0.2 \mathrm{ppm}$ during this sampling period (29 Sept. to 10 Oct.) can be described for the NTC by the following linear regression equation: $\mathrm{Y}=33.3+3.93 \mathrm{x}, \mathrm{r}^{2}=0.79$, and for the $3+6$ WAFB treatment by the following polynomial: $\mathrm{Y}=65+5.54 \mathrm{x}-$ $0.23 \mathrm{x}^{2}, \mathrm{r}^{2}=0.63$.

\section{Discussion}

In this long-term study, ethephon applied in "on years" of strongly alternate bearing spur-type 'Delicious' apple increased flowering in "off years," reduced flowering, with one exception, in "on years," and reduced variability and magnitude of alternate cropping (Table 1, Fig. 2). The timing of our ethephon treatments was selected to bracket the period of flower initiation and merits further comment. Ethephon applied at $3+6$ and $3+6+9$ WAFB in "on years" increased flowering by $30 \%$ to $50 \%$ in all three "off years" (Table 1, Fig. 2). These two treatments did not differ from each other. Ethephon applied in "on years" at 3 WAFB, with one exception (Table 1, year 2003), did not differ from NTC. Because ethephon applied at 3 WAFB had no significant effect on flowering, and treatment at $3+6+9$ WAFB was no more effective than $3+6$ WAFB, one may hypothesize that the ethephon dose delivered at 6 WAFB was most effective. The exact time of flower initiation is not known, and there is no specific index available to predict time of initiation, and, hence, target chemical application to affect flower initiation. Based on morphologic studies after the doming of the narrow, pointed vegetative meristem or the slowing plastochron of primordial formation to approximately six, flower initiation is presumed to occur 3 to 6 WAFB (Abbott, 1970; Buban and Faust, 1982; Fulford, 1966; Pratt, 1988; Pratt et al., 1959; Tromp, 1976) and may occur later (8-10 WAFB) in light cropping or vigorous trees (Buban and Faust, 1982) and on current season shoots (McArtney et al., 2001).

In a recent time-course study of meristem development on bourse shoots of 'Royal Gala', meristems were classified as 1) vegetative, 2) "vegetative committed to become floral meristems," 3) inflorescence, and 4) floral meristem (Foster et al., 2003). If we extrapolate their data to our treatment times, we could expect that $\approx 55 \%, 41 \%$, and $32 \%$ of the meristem population would be in the vegetative stage at our treatment times of 3 , 6 , and 9 WAFB, respectively. Thus, our 6 WAFB treatment would have just preceded the peak $(\approx 70 \%)$ of the "competent meristem to flower population" by $11 \mathrm{~d}$. Ethephon treatment near this time may more selectively target the highest proportion of the population of meristems at the most sensitive developmental stage for flower initiation.

Our data provide evidence that ethephon had a direct effect on flowering without affecting flower quality in apple, because 1) flower initiation was increased in "on years" without reducing yield (Tables 1 and 2), 2) ethephon had no significant effect on observed vegetative growth (see text), and 3 ) trees treated with ethephon initiated more flowers per kilogram of fruit produced than did the NTC (Table 6). Ethephon may also have had an indirect affect by reducing bloom density in "on years" as a result of increased cropping in "off years" (Tables 1 and 2). Greene et al. (1977) also observed an increase in return bloom with ethephon in the absence of significant fruit thinning or reduced shoot growth, but only at higher concentrations $\left(500-1000 \mathrm{mg} \cdot \mathrm{L}^{-1}\right)$. The amount of fruit produced per unit of bloom in both "on" and "off" years was not affected by ethephon (Table 7). This confirms that flower quality was not compromised. This finding differs from that of Greene et al. (1977) in which ethephon $\left(500-1000 \mathrm{mg} \cdot \mathrm{L}^{-1}\right)$ increased return bloom, but not yield, as measured by fruit set per unit area of fruiting limbs.

Increases in return bloom observed in most other studies, particularly on young, lightly cropping trees, were always associated with reduced shoot growth or crop load, both known to be related to flower initiation (Byers, 1993; Byers and Carbaugh, 1991; Marini, 1996; Tromp, 2000; Voltz and Knight, 1986). There is the possibility that in our study ethephon may have induced a transient inhibition of shoot growth that was not detected at our time of shoot measurement. A transient inhibition of shoot growth, if it occurred, would not be expected 
Table 6. Effect of ethephon ( $\left.200 \mathrm{mg} \cdot \mathrm{L}^{-1}\right)$ applied as a foliar spray at $3,3+6$, and $3+6+9$ weeks after full bloom (WAFB) in two frost-free "on years" $(1998,2000)$ on flower initiation in spur-type "Delicious".

\begin{tabular}{lcccc}
\hline & \multicolumn{4}{c}{ Ethephon } \\
\cline { 2 - 5 } Yr & NTC & 3 & $3+6$ & $3+6+9$ WAFB $^{\mathbf{z}}$ \\
\hline & $14 \mathrm{a}^{\mathrm{y}}$ & $18 \mathrm{ab}$ & (Flowers $/ \mathrm{kg}$ fruit) $^{\mathrm{z}}$ & $20 \mathrm{ab}^{\mathrm{x}}$ \\
Percentage of NTC & 100 & 129 & 143 & $23 \mathrm{~b}$ \\
2000 & $32 \mathrm{a}$ & $37 \mathrm{ab}$ & $46 \mathrm{~b}$ & 164 \\
Percentage of NTC & 100 & 116 & 144 & $48 \mathrm{~b}$ \\
\hline
\end{tabular}

${ }^{2}$ See text for calculation of flowers $/ \mathrm{kg}$ fruit.

${ }^{y}$ Means within a year followed by the same letter are not significantly different at $P=0.05$ by Tukey's HSD test.

${ }^{x}$ Significant from NTC at $P=0.10$

Table 7. Effect of ethephon (200 mg. $\left.\mathrm{L}^{-1}\right)$ applied as a foliar spray $3,3+6$, and $3+6+9$ weeks after full bloom (WAFB) in "on years" $(1998,2000)$ on amount $(\mathrm{kg})$ of fruit produced per unit of bloom in each of three seasons.

\begin{tabular}{llccc}
\hline & \multicolumn{4}{c}{ Ethephon $^{\mathrm{z}}$} \\
\cline { 2 - 5 } Yr (off/on) & \multicolumn{1}{c}{ NTC } & 3 & $3+6$ & $3+6+9$ WAFB $^{z}$ \\
\hline 1999 (off) & $19.1 \pm 10.1$ & $18.0 \pm 6.2$ & $21.5 \pm 5.0$ & $21.8 \pm 9.1$ \\
2000 (on) & $16.8 \pm 2.9$ & $15.3 \pm 3.3$ & $15.9 \pm 2.7$ & $16.8 \pm 4.7$ \\
2001 (off) & $14.6 \pm 7.3$ & $12.9 \pm 4.5$ & $14.7 \pm 5.2$ & $14.1 \pm 5.3$ \\
\hline
\end{tabular}

${ }^{\mathrm{z}}$ Data in $\mathrm{kg} / \mathrm{unit}$ bloom $\pm \mathrm{SD} . \mathrm{n}=24$ trees. Differences within a year were not significant at $P=0.05$ by Tukey's HSD test.

Table 8. Effect of ethephon ( $\left.200 \mathrm{mg} \cdot \mathrm{L}^{-1}\right)$ applied as a foliar spray at $3+6$ weeks after full bloom (WAFB) on internal ethylene concentration (IEC), firmness, starch index, and soluble solids of Redchief 'Delicious' fruit on three sampling dates preceding harvest in $2002^{\mathrm{z}}$.

\begin{tabular}{llcccc}
\hline $\begin{array}{l}\text { Days before } \\
\text { harvest }\end{array}$ & Treatment & $\begin{array}{c}\text { IEC } \\
\text { (\% fruit }>0.2 \text { ppm) }\end{array}$ & Firmness (N) & $\begin{array}{c}\text { Starch index } \\
(1-8)\end{array}$ & $\begin{array}{c}\text { Soluble } \\
\text { solids (\%) }\end{array}$ \\
\hline 14 & NTC & 32.5 & 73.4 & 2.5 & 10.9 \\
& Ethephon & 65.0 & 75.2 & 2.4 & 11.7 \\
7 & NTC & 62.5 & 75.6 & 2.7 & 11.7 \\
& Ethephon & 92.5 & 74.7 & 3.0 & 12.2 \\
1 & NTC & 87.5 & 70.7 & 5.4 & 12.2 \\
& Ethephon & 97.5 & 71.6 & 6.0 & 12.7 \\
\hline
\end{tabular}

${ }^{2}$ No differences $(P=0.05)$ were found between NTC and ethephon, within a sampling date, for any of the measurements. Change in percentage of fruit exceeding IEC of $0.2 \mathrm{ppm}$ over a 14-d period immediately before harvest is described by the linear equation $\mathrm{Y}=33.3+3.93 \mathrm{x}, \mathrm{r}^{2}=0.79$ for NTC and by the polynomial equation $\mathrm{Y}=65+5.54 \mathrm{x}-0.23 \mathrm{x}^{2}, \mathrm{r}^{2}=0.63$ for $3+6$ WAFB

to have a significant effect on flowering, because both transient and prolonged inhibition of shoot growth induced by prohexadione-Ca [3-5-dioxo-4-1-(1-oxopropyl)cyclohexane carbonate, Apogee] in cropping apple trees did not increase return bloom (Wise et al., 2005; R.E. Byers and S.S. Miller, personal communication).

The ethephon effect on yield in both "on" and "off" years closely followed the effect on flowering (Tables 1 and 2, Fig. 2). Ethephon applied in "on years" did not significantly alter yield in the year of application. However, in the third "on year" (2002), the year of frost, yields for the $3+6$ and $3+6+9$ ethephon treatments were considerably lower. Much of this reduction can be related to less bloom; however, because bloom was unaffected by the frost, we have no adequate explanation for this anomaly. Yields in the "off years" were significantly increased by ethephon except in the season after the frost (Table 2, year 2003). This reflects the marked reduction in yield in 2002 promoting a strong return bloom and hence increased yield in the expected "off year" 2003.

The long-term effects of ethephon on cropping of these alternate-bearing trees are best illustrated by comparing yields over the entire 6-year study, i.e., three "on years" and three "off years" (Table 5). Comparing data for the NTC and $3+6$ WAFB ethephon treatment only, and pooling for each the data for the three "on years" and three "off years," we found no difference in mean yield between the NTC and ethephon treatment (Table 5). However, comparing the treatment effect for "on" versus "off" years, ethephon reduced yield in "on years" by $10 \%$ and increased yield in "off years" by $24 \%$. Not only was a portion of the crop shifted from the "on years" to "off years," but variation in yield per tree in "off years" was markedly reduced. If we compare the ethephon response for only the first 4 frost-free years (1998-2001 for yield, 1999-2002 for bloom), ethephon increased the total yield by $\approx 7 \%$ ( $85 \mathrm{vs.} 91 \mathrm{~kg} /$ tree), decreased cropping in "on years" by $\approx 5 \%$ (127 vs. $121 \mathrm{~kg} /$ tree), and increased yield in the "off years" by $\approx 43 \%$ (42 vs. $60 \mathrm{~kg} /$ tree). Ethephon increased flowering by $31 \%$ in the "off years" and reduced it by $14 \%$ in the "on years."

The CV for the yield per tree $(n=48)$ over two "off years" $(1999,2001)$ was $47 \%$ for NTC compared with $26 \%$ for the ethephon treatment $(3+6$ WAFB $)$, a reduction in variation of $\approx 45 \%$. The variation for the NTC and ethephon treatment was considerably lower and similar in the "on years" $(16 \%$ vs. $15 \%)$. Both a shift of a portion of the crop from "on years" to "off years" and an increase in uniformity of cropping are favorable characteristics for efficient cultural practices and economics of production.

The overall strong alternation pattern for flowering and yield was not significantly altered by ethephon (Tables 1 and 2, Fig. 2). The Hoblyn parameter B, which estimates the tendency for alternation, was the highest possible (B equaled 100). In contrast, the intensity of alternation was significantly reduced $(\approx 35 \%)$ as measured by the Hoblyn I parameter (Table 3 ). This probably reflects the increased flower initiation induced in the "on years" by ethephon and the subsequent effect on the increased cropping in the "off years." Our I values were similar to those published $(\approx 49-75 \%$ ) for Redchief 'Delicious' grown on over 20 rootstocks for a 6- to 8-year period (Barritt et al., 1995; Ferree et al., 1995). Frost in year 2002 interrupted the alternation pattern by markedly reducing yield, which in many cases is known to induce alternation in regularly cropping trees (Monselise and Goldschmidt, 1982).

Our ethephon treatments produced no significant changes in common harvest maturity indices. Ethephon produced no significant changes in IEC, starch index, or soluble solids as fruit approached maturity. These results were consistent, in part, with the published data, but not when higher concentrations and earlier or later applications times were used (Greene et al., 1977; Byers and Carbaugh, 1991; Beaudry et al., 1993; Watkins et al., 2005).

In conclusion, ethephon applied to strongly alternate bearing 'Delicious' trees increased flower initiation and, significantly, increased cropping in the next "off years." The effect on flower initiation was observed without a reduction in yield or shoot growth. The optimum time of application was estimated as 6 WAFB. Our data provide a basis for optimizing the use of ethephon (e.g., dose, time, and cultivar) as a practice to complement blossom/fruit thinning as a means of reducing alternate bearing.

\section{Literature Cited}

Abbott, D.L. 1970. The role of budscales in the morphogenesis and dormancy of apple fruit bud, p. 65-82. In: Luckwill L.C. and C.V Cutting (Eds.). Physiology of Tree Crops Academic Press, New York.

Barritt, B.H., B.S. Kanishi, and M.A. Dilley. 1995. Performance of three apple cultivars with 23 dwarfing rootstocks during 8 seasons in Washington. Fruit Var. J. 49:158-170.

Batjer, J.P., M.W. Williams, and G.C. Martin. 1964. Effect of N-dimethylamino succinic acid (B-nine) on vegetative and fruit characteristics of apples, pears and cherries. Proc. Amer. Soc. Hort. Sci. 85:11-16.

Beaudry, R.M., P. Schwallier, and M. Lennington. 1993. Apple maturity prediction: An extension 
tool to aid fruit storage decision. HortTechnology 3:233-239.

Buban, T. and M. Faust. 1982. Flower bud induction in apple trees: Internal control and differentiation. Hort. Rev. (Amer. Soc. Hort. Sci.) 4:174-203.

Bukovac, M.J. 1968. Chemical promotion of flowering. Amer. Fruit Grower 88:18.

Byers, R.E. 1993. Controlling growth of bearing apple trees with ethephon. HortScience 11:1103-1105.

Byers, R.E. 2002. Effect of thinning time on yield, fruit size, and return bloom of 'York' and 'Golden Delicious' apple trees. J. Tree Fruit Prod. 3:55-63.

Byers, R.E. and J.A. Barden. 1976. Chemical control of vegetative growth and flowering of non-bearing 'Delicious' apple trees. HortScience 11:506-507.

Byers, R.E. and D.H. Carbaugh. 1991. Effect of chemical thinning sprays on apple fruit set. HortTechnology 1:41-48.

Davis, L.D. 1957. Flowering and alternate bearing. Proc. Amer. Soc. Hort. Sci. 70:545-556.

Ferree, D.C., P.M. Hirst, J.C. Schmid, and P.E. Dotson. 1995. Performance of three apple cultivars with 22 dwarfing rootstocks during 8 seasons in Ohio. Fruit Var. J. 49:171-178.

Foster, T., R. Johnston, and A. Seleznyova. 2003. A morphological and quantitative characterization of early floral development in apple (Malus $\times$ domestica Borkh.). Ann. Bot. (Lond.) 92:199206.
Fulford, R.M. 1966. The morphogenesis of apple buds. III. The inception of flowers. Ann. Bot. (Lond.) 30:207-219.

Greene, D.W., W.J. Lord, and W.J. Bramlage. 1977. Mid-summer application of ethephon and daminozide on apples. I. Effect on 'Delicious'. J. Amer. Soc. Hort. Sci. 102:491-494.

Harley, C.P., H.H. Moon, and L.O. Regeimbal 1958. Evidence that post-bloom apple thinning sprays of naphthaleneacetic acid increase blossom-bud formation. Proc. Amer. Soc. Hort. Sci. 72:52-56.

Hoblyn, T.N., N.H. Grubb, A.C. Painter, and B.L. Wates. 1936. Studies on biennial bearing. I.J. Pomol. 14:39-79.

Jonkers, H. 1979. Biennial bearing in apple and pear: A literature survey. Scientia Hort. 11:303-406.

Luckwill, L.C. 1970. Control of growth and fruitfulness of apple trees, p. 237-254. In: L.C Luckwill, and C.V. Cutting (Eds.). Physiology of Tree Crops. Academic Press, NY.

Marini, R.P. 1996. Chemical thinning spur 'Delicious' apples with carbaryl, NAA, and ethephon at various stages of fruit development. HortTechnology 6:241-246.

McArtney, S.J., E.M. Hoover, P.M. Hirst, and I.R. Brooking. 2001. Seasonal variation in the onset and duration of flower development in 'Royal Gala' apple buds. J. Hort. Sci. Biotechnol. 76:536-540.

Monselise, S.P. and E.E. Goldschmidt. 1982. Alternate bearing in fruit trees. Hort. Rev. (Amer. Soc. Hort. Sci.) 4:129-173.
Pearce, S.C. and S. Doberšek-Urbanc. 1967. The measurement of irregularity in growth and cropping. J. Hort. Sci. 42:295-305.

Pratt, C. 1988. Apple flower and fruit: Morphology and anatomy. Hort. Rev. (Amer. Soc. Hort. Sci.) 10:273-308.

Pratt, C., J. Einset, and M. Zahur. 1959. Radiation damage in apple shoot apices. Amer. J. Bot. 46:537-544.

Singh, L.B. 1948. Studies in biennial bearing II. A review of the literature. J. Hort. Sci. 24:45-65.

Tromp, J. 1976. Flower-bud formation and shoot growth in apple as affected by temperature. Scientia Hort. 5:331-338.

Tromp, J. 2000. Flower-bud formation in pome fruits as affected by fruit formation. Plant Growth Reg. 31:27-34.

Voltz, R.K. and J.N. Knight. 1986. The use of growth regulators to increase precocity in apple trees. J. Hort. Sci. 61:181-189.

Watkins, C.B., M. Erkan, J.F. Nock, K.A. Lungerman, R.M. Beaudry, and R.E. Moran. 2005. Harvest date effects on maturity, quality, and storage disorders of 'Honeycrisp' apples. HortScience 40:1-6.

Williams, M.W. 1979. Chemical thinning of apples. Hort. Rev. (Amer. Soc. Hort. Sci.) $1: 270-300$.

Wise, J.C., L.J. Gut, R. Isaacs, A.M.C. Schilder, G.W. Sundin, B. Zandstra, E. Hanson, and B. Shane. 2005. Michigan fruit management guide. Mich. State Univ. Ext. Bul. E-154: 149-150. 